\title{
SUSTAINABLE OPERATIONAL ANALYSIS OF THE CULTIVATION OF INDONESIAN Thunnus albacares BY BIOECONOMIC APPROACH
}

\author{
Mimit Primyastanto*, Rizky Agung Lestariadi, Ade Khadar Haris
}

Department of Marine and Fisheries Social Economic, Faculty of Fisheries and Marine Science, Brawijaya University, Malang 65145, East Java, Indonesia

*Corresponding Author: mimitp@ub.ac.id

\section{ARTICLE INFO}

Received: 6 May 2020

Accepted: 12 January 2021

\section{Keywords:}

Maximum sustainable yield

Maximum economic yield

Tuna resource

Economic overfishing

Biological overfishing

\section{ABSTRACT}

This study aimed to describe the characteristics and cultivation conditions of Thunnus albacares in Pelabuhan Perikanan Pantai (PPP, shore-port fisheries) of Labuhan Lombok, East Lombok. Data was collected by a simple random sample using a questionnaire for 30 fishing boats. Primary data was collected by interview with respondents and field observation, while secondary data was obtained from records of PPP in Labuhan Lombok, BPS and DKP, East Lombok. Results showed that East Lombok has a high potential for T. albacares cultivation as well as eco-friendly fishery cultivation; this is practiced by local fishermen who commonly use traditional boats sized 4-7 GT complete with fishing utilities, including handline rods and trolling rods. From a biological aspect, there was open access to T. albaceros in 2006, followed by biological overfishing in 2007, and economic overfishing in 2005, 2008, 2009, 2010 and 2011. The maximum sustainable yield (MSY) reached 922,518.18 kg per year (MSY level 3,313 per year). The resource optimization of $T$. albaceros reached the peak of maximum economic yield (MEY) valued at IDR 24,693,982,361, with fish haul efforts from 2,063 annual trips yielding $791,270.90 \mathrm{~kg}$ of tuna per year.

Primyastanto, M., Lestariadi, R. A., Haris, A. K. (2021): Sustainable operational analysis of the cultivation of Indonesian Thunnus albacares by bioeconomic approach. Croatian Journal of Fisheries, 79, 61-70. DOI: 10.2478/cjf-2021-0007. 


\section{INTRODUCTION}

Indonesia has a very high potential for fish production thanks to the abundant resources. However, open-access fishing allowing anyone to haul fish leads to an overfishing issue because there are no ownership rights to the sea area. The sea area of Indonesia is common property and open access. Therefore, the commercial fishery cannot be controlled directly by an owner with ownership rights, including the right to utilize and exploit the property. Commonly, the sea resource is open to exploitation by anyone (unlimited entry), which can lead to overexploitation.

One of the best fishery products is tuna. Tuna is one of the most important economical commodities in Indonesia, both for domestic consumption and export (Sumandhiharga, 2009). There are many types of tunas, but there are four species that are the dominant commodities in production: cakalang (skipjack tuna, Katsuwonus pelamis), madidihang (yellowfin tuna, Thunnus albacares), tuna mata besar (bigeye tuna, $T$. obesus) and tuna sirip biru (Atlantic bluefin tuna, T. macoyii) (Saanin, 1984). Commonly, these tunas are collected using fishing utilities such as handline rod, pole and line, longline, trolling rod, purse seine, purse seine mini and gillnet (Sudirman and Mallawa, 2004).

One of the areas with the highest potential to produce the best fish commodities is the East Lombok District located in West Nusa Tenggara, Indonesia, which has an area of $10,743.22 \mathrm{~km}^{2}$ (40.99\% of area). The shoreline stretches $220 \mathrm{~km}$ from the south to the north. The development potential of the shores and small islands nearby includes six sub-districts, 22 village areas and 16,434 citizens who are employed as fishermen (Ministry of Marine Affairs and Fisheries, 2014).

The East Lombok fisheries have potential production reaching 12,691 tons. In 2009, the fishery sector economically yielded IDR $150,709,100,000$ from the fish haul operated by 461 traditional boats, 3,132 semimotorboats and 345 motorboats. The fish haul areas included the Alas Strait, the Indian Ocean and the Java Sea (Supadiningsih and Rosana, 2004). The yield included more than 50 types of fishes. Based on 2009 data, the fish species with more than 1,000 tons collected were Thunnus sp. (Local: tongkol, 2000 tons), K. pelamis (Local: cakalang, $1,666.5$ tons) and $T$. albacares (1,163 tons) (Habibi et al., 2011). Dahuri (2008) stated that $T$. albacares and $T$. obesus can be found throughout Indonesian territorial waters. Meanwhile, albacore (T. alalunga) live in the west of Sumatra, South Bali and East Nusa Tenggara. Southern bluefin tuna (T. maccoyii) only live south of Java in the southern Indian Ocean, which has lower temperatures.

The most promising and busy port at the center of fish production in East Lombok is Tanjung Luar, where 5,610 tons of fish were collected and sold in 2009.
The other promising ports are Labuhan Lombok $(5,205$ tons), Batu Nampar (1,025 tons), Labuhan Haji $(3,627$ tons) and East Sakra (259 tons) (Ministry of Marine Affairs and Fisheries, 2014). The high yield of fish brings benefits to the Indonesian economy. However, the promising factor of fish and fish products leads to overfishing, especially since there is no limitation to fish collected per fishing by each person. This will threaten the sustainability of fish resources, especially one of the most promising fish commodities - tuna. The exploitation is important for benefiting the economy, but the fish resource needs to maintain its sustainability from a biological aspect.

In order to maintain the fishery sector, attention must be paid to both biological and economic factors. The bioeconomic Gordon-Schaefer Model is a fishery analysis model that could be applied to the utilization and maintenance of fish resources. This study aimed to describe the fishery sector of $T$. albacares, analyze the actual condition of the operating $T$. albacares fishery and determine the optimal level of the utilization of $T$. albacares from a biological and economical perspective.

\section{MATERIAL AND METHODS}

\section{Sampling}

This study used the descriptive method of survey data collection. Thirty fishermen in Pelabuhan Perikanan Pantai (PPP, shore-port fisheries) in East Lombok were selected randomly to ensure homogeneity of the sample population. Hasan (2002) suggested that a larger sample size in a study will give more representative results. However, the number of samples depends on the study type. T. albacares is widely spread in the oceans, including the Atlantic, Pacific and Indian Oceans, with preferred temperatures between $17-31^{\circ} \mathrm{C}$ (optimum $19-23^{\circ} \mathrm{C}$ ). To collect this fish by fishery haul, the best temperature is $14-27^{\circ} \mathrm{C}$ (optimum $21-22^{\circ} \mathrm{C}$ ) (Fig. 1) (Sumandhiharga, 2009).

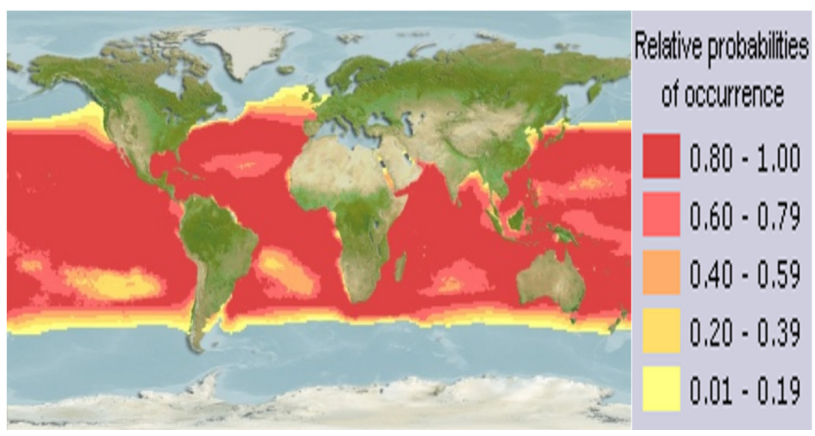

Fig 1. The distribution of Thunnus albacares (Fishbase 2016) 


\section{Data collection}

The population of this study was the fishing fleet in the PPP Labuhan, East Lombok. For this data collection, the primary data including in-field data by interview and PPP Labuhan observation was gathered. The themes of the interview included the operation costs of $T$. albacares fishing, the length of fish haul (in days) and areas of fishing. The observation was performed to understand the PPP Labuhan conditions and supporting facilities. The secondary data gathered included the fishing yield for 11 years prior (2005-2015), the market price of T. albacares, the number of boats in the fishing fleet that operated in PPP Labuhan and the consumer price index (CPI) data.

\section{Data analysis}

The most important step in the study was divided into several stages:

\section{(1) Fish yield per fishing effort}

The time-series data from the production and fishing effort was used to presume biological and bioeconomic model of technological parameters (Primyastanto, 2018b). The production data per year was divided by the fishing effort per year to determine CPUE (Equation 1) (Schaefer, 1954).

$$
C P \cup E_{t}=Y_{t} / E_{t}
$$

Information:

$$
\begin{array}{ll}
\text { CPUE }_{t} & : \text { CPUE in specific time } t \\
\mathrm{Y}_{\mathrm{t}} & : \text { Fish yield in specific time } t \\
\mathrm{E}_{\mathrm{t}} & : \text { Fishing efforts in specific time } t .
\end{array}
$$

To standardize the different fishing efforts, the equation for the Gulland method was used (Equation 2) (Pradana, 2015).

$$
E_{s t d}=\left(C P \cup E_{n} / C P \cup E_{s t d}\right) \times E_{n}
$$

Information:

$$
\begin{array}{ll}
E_{s t d} & : \text { Standardized total fishing efforts (trips) } \\
C P U E_{n} & \begin{array}{l}
\text { : CPUE fish haul utilities which will be standardized } \\
\text { (kg/trip) }
\end{array} \\
\text { CPUE } & \text { : CPUE standard fish haul utilities ( } \mathrm{kg} / \mathrm{trip}) \\
E_{n} & \begin{array}{l}
\text { : Fishing attempt with standardized fishing gear } \\
\text { (trips) }
\end{array}
\end{array}
$$

(2) The function of fishery sustainable productivity

The function of production that depicts the level of fish haul efforts and sustainable production is equation 3 (Equation 3) (Schaefer, 1954; Fauzi, 2010).

$$
\begin{aligned}
& h=q K E(1-q E / \mathrm{r}) \\
& h=q K E-\left(\left(q^{2} K E^{2}\right) / \mathrm{r}\right) \\
& \text { if } q K=\alpha \text { and }\left(q^{2} K\right) / \mathrm{r}=\beta \text {, then it can be simplified to: } \\
& h=\alpha E-\beta E^{2} \\
& \text { Information: } \\
& \mathrm{h} \quad=\text { fish yield } \\
& \mathrm{E} \quad=\text { fishing effort level } \\
& \mathrm{q} \quad=\text { coefficient fishing capability } \\
& \mathrm{K} \quad=\text { environment supporting capacity }
\end{aligned}
$$

$r=$ natural growth rate

$\alpha, \beta=$ CPUE regression coefficient with effort

The $E_{m s y}$ value can be obtained by generating the mathematical equation (Equation 3); mathematically, the fishing efforts performed in order to reach the maximum sustainable yield can be described by the following equation:

$$
\begin{aligned}
& \delta h / \delta E=\alpha-2 \beta E=0 \\
& E_{m s y}=\alpha / 2 \beta
\end{aligned}
$$

Information:

$E_{m s y}=$ fishing efforts to reach the maximum sustainable yield.

(3) Economical profit analysis

The economic profit was analyzed using the GordonSchaefer model. The profit obtained is calculated by subtracting the total cost (cost of fish haul) from the total revenue (Equation 5 ).

$$
\begin{aligned}
\pi & =T R-T C \\
& =p \cdot h-c \cdot E \\
& =p \cdot\left(\alpha E-\beta E^{2}\right)-c \cdot E
\end{aligned}
$$

Information:

$\mathrm{p} \quad=$ average price $T$. albacares (IDR per $\mathrm{kg}$ )

$\mathrm{h}=$ fish haul yield $(\mathrm{kg})$

c = cost fish haul effort (IDR per trip)

$\mathrm{E} \quad=$ the amount of fish haul effort (trips per year)

In the maximum economic yield condition, the fishing attempt will obtain the maximum profit in the operation of fishery resources $\left(E_{m e y}\right)$. By generating the derivative of equation 5 towards fishing attempts $(E)$, the expected level of attempts will be obtained, and the resulting formula is:

$$
\begin{aligned}
& =p \cdot h-c \cdot E \\
& =p \cdot\left(\alpha E-\beta E^{2}\right)-c \cdot E \\
& E_{m e y}=\delta \pi / \delta E=p \cdot(\alpha-2 \beta E)-c=0 \\
& =(p \cdot \alpha-c) / 2 \beta p
\end{aligned}
$$

Because the equation obtained a polynomial number, the Maple 18 Program was used to generate the equation numerically. When the system met the bioeconomic balance $(\pi=0)$, the fish haul level was in open-access condition, which is mathematically described by the following equation (Equation 7):

$$
\begin{aligned}
& T R-T C=0 \\
& p \cdot h-c \cdot E=0 \\
& p \cdot\left(\alpha E-\beta E^{2}\right)-c \cdot E=0 \\
& p \cdot(\alpha-\beta E)-c=0 \\
& p \alpha-p \beta E-c=0 \\
& E_{o a}=(p \cdot \alpha-c) / p \beta
\end{aligned}
$$

Information:

$E_{\text {mey }} \quad=$ fish haul yield needed to reach the MEY (trip)

$E_{o a} \quad=$ fish haul during open access conditions (trip)

$\mathrm{p}=$ = average price of $T$. albacares (IDR per kg)

$\mathrm{C} \quad=$ cost (IDR per trip) 
The bioeconomic model is influenced by economic parameters such as fishing cost (c) and price of fishing yield $(p)$. The parameter of fishing cost (c) is calculated from the respondents' (fishermen) expenses. The fishing cost in the bioeconomy field of the Gordon-Schaefer Model is based on the assumption that the fishing cost is the only parameter that is calculated (Sobari et al., 2004). The average cost is calculated with the following equation (Equation 8):

$$
c=(\Sigma c i) / n
$$

Information:

$$
\begin{array}{ll}
\mathrm{ci} & =\text { cost of specific respondent } i \\
\mathrm{C} & =\text { average cost }(\mathrm{Rp}) \text { per trip per year } \\
\mathrm{n} & =\text { total respondents }
\end{array}
$$

The real average price from 2009-2015 was used to determine the variable price of tuna $(p)$. Nominal price was adjusted to real price using the following equation (Equation 9):

$$
\begin{array}{ll}
\mathrm{P}_{\text {rt }} & =\text { real price in specific period } t \\
\mathrm{P}_{n t} & =\text { nominal price in specific period } t \\
\mathrm{CPI}_{\mathrm{t}} & =\text { customer price index in specific period } t \\
\mathrm{CPI}_{\mathrm{d}} & =\text { customer price index in the basic year period }
\end{array}
$$

The assumptions used in the study by Fauzi (2010) were:

1. The fish resource is a single species.

2. Fishermen could not determine the prices.

3. The price per $\mathrm{kg}$ is constant.

4. Market structure is competitive.

5. The fish haul cost is constant, including the cost of fishing equipment: fishing handline rods and trolling rods.

6. There is only one fishing factor that is calculated (did not include the post-fishing or other factors).

7. The boat has relatively the same size and is equipped with the same fishing utilities.

\section{RESULTS}

\section{The fish haul per fishing effort}

The fish yield increased between 2005 and 2015 relative to the decrease in the fish haul effort in PPP Labuhan. CPUE describes the fish yield per boat unit per year. The highest CPUE happened in 2015 when it reached 489,340 kg per trip, and the lowest happened in 2006 with 343,789 kg per trip (Fig. 2).

There is a negative relation between CPUE and fishing effort, indicating that the more boats fishing the fish, the lower the yield of fish (Fig. 3).

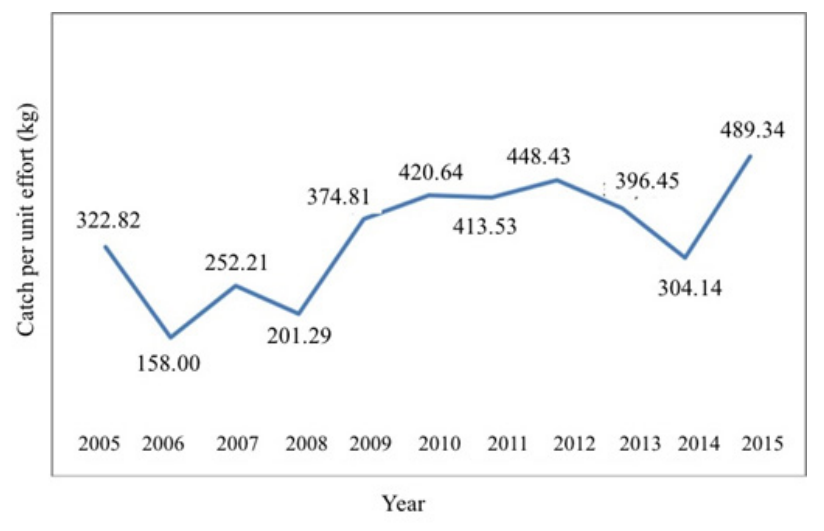

Fig 2. The fish yield per fish haul (CPUE) from 2005-2015 at PPP Labuhan Lombok, East Lombok

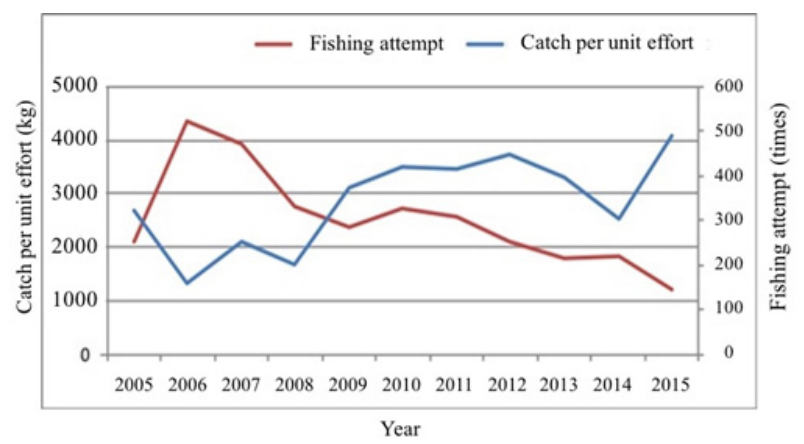

Fig 3. The CPUE relation to fish haul from 2005-2015 in PPP Labuhan Lombok, East Lombok

\section{The function of sustainable tuna production}

The regression coefficients are $\alpha$ and $\beta$, where both slope and interslope are used to assume the function of sustainable production in the equation $h=\alpha E-\beta E^{2}$. The fishing yield $(\mathrm{kg})$ is $h$, while the effort of fishing is $E$ (trips) per year. The Gordon-Schaefer Model is used to estimate the MSY (maximum sustainable yield) of tuna in East Lombok (Fig. 4).

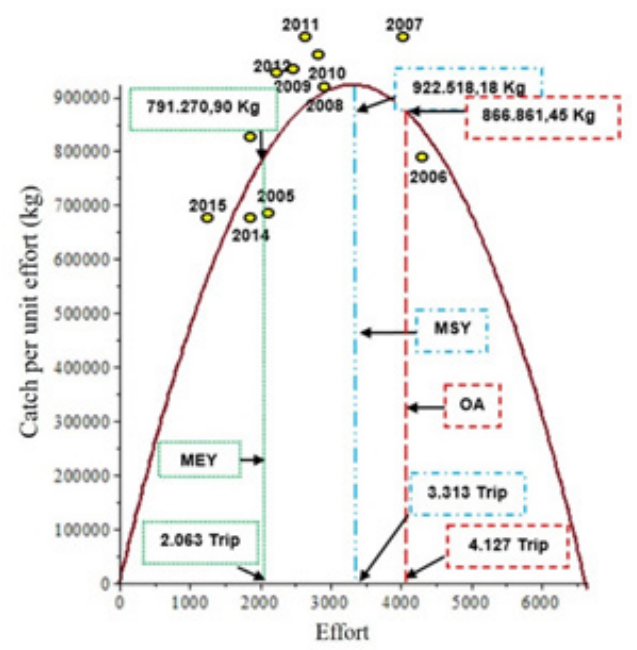

Fig 4. The quadratic relation between fish haul effort and fish yield based on the Gordon-Schaefer Model in East Lombok seas 
Both regression coefficients $\alpha$ and $\beta$ are determined by a simple linear regression method, with effort level as the independent variable $(\mathrm{x})$ and CPUE as the dependent variable (y). It obtained a regression result of $\alpha=556,746$ and $\beta=-0.084$. The function of sustainable production is $h=556,746 \times \mathrm{E}-(-0.084) \times \mathrm{E}^{2}$. The regression coefficient value based on Maple 18 was $E_{m s y}=3.313$ per trip. This explains the maximum total trips that boats or fishing fleets can take without disrupting the sustainability of the natural $T$. albacares resource in East Lombok seas. The function between sustainable $T$. albacares and fish haul effort in East Lombok is parabolic or quadratic, indicating that the more fish haul effort $(E)$ performed, the more fish yield until it reaches the maximum point. The fish yield will decrease if the fish haul effort exceeds its maximum point. The calculation of sustainable fish yield (MSY) is described in this mathematical equation $h_{m s y}=631,689(3313)-\left(-0.084\left(3,313^{2}\right)\right)=922,518.18 \mathrm{~kg}$ per year. The underfishing in PPP Labuhan also caused the fishermen to lose their profit because the income is surely lower than the fishing cost (Table 1).

\section{The economic aspect of $T$. albacares resource utilization}

In 2016, the cost that was needed by fishermen was IDR 8.4 million (Table 2). The variable cost of 2016 became the fishing cost standard from 2005-2015 that included the $\mathrm{CPI}$ in the calculation. The fishing cost was obtained from the average cost from all 30 respondents in PPP Labuhan, East Lombok.

The total cost (TC) calculation for the average fish boat uses the calculation $T C=6,553,621.01 \times \mathrm{E}$, as calculated by Maple 18 (Table 3). There is a relation between TC and effort in PPP Labuhan, East Lombok (Fig. 5), which indicated that there is a linear relation in which the more effort increases, the TC will also increase per 6,553,621.01.

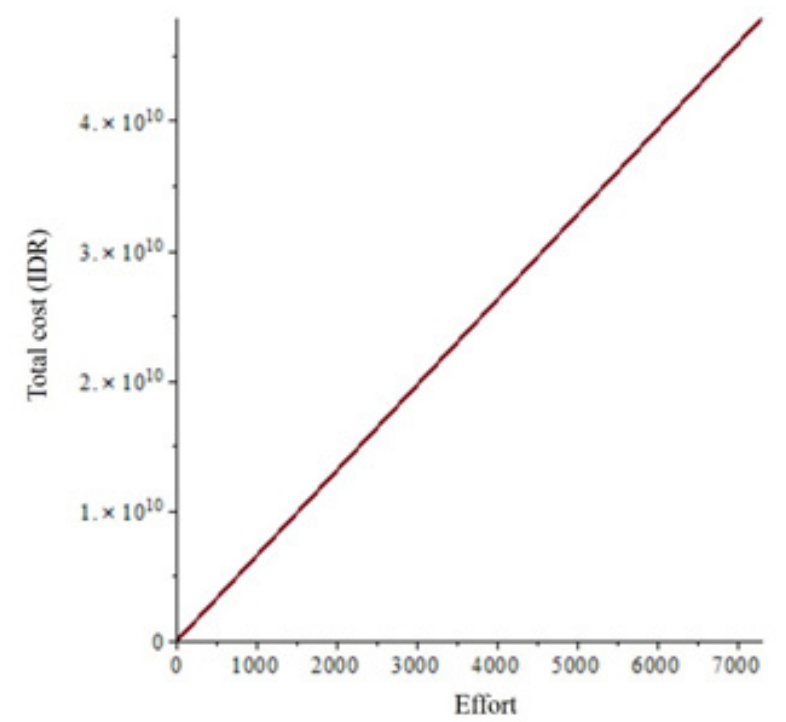

Fig 5. Linear relation between total cost (TC) and effort (E)

Table 1. Actual fish haul 2005-2015

\begin{tabular}{|c|c|c|c|c|c|c|}
\hline \multirow[b]{2}{*}{ No. } & \multicolumn{6}{|c|}{ EFFORT (Trip) } \\
\hline & Year & Actual condition & $\begin{array}{c}\text { Sustainable condition } \\
\text { (MSY) }\end{array}$ & $\begin{array}{l}\text { Bio economic optimization } \\
\text { (MEY) }\end{array}$ & $\begin{array}{c}\text { Open Access } \\
(O A)\end{array}$ & Information ${ }^{a}$ \\
\hline 1 & 2005 & 2090 & 3313 & 2063 & 4127 & Economic Overfishing \\
\hline 2 & 2006 & 4352 & 3313 & 2063 & 4127 & Open Access \\
\hline 3 & 2007 & 3936 & 3313 & 2063 & 4127 & Biological Overfishing \\
\hline 4 & 2008 & 2765 & 3313 & 2063 & 4127 & Economic Overfishing \\
\hline 5 & 2009 & 2386 & 3313 & 2063 & 4127 & Economic Overfishing \\
\hline 6 & 2010 & 2745 & 3313 & 2063 & 4127 & Economic Overfishing \\
\hline 7 & 2011 & 2574 & 3313 & 2063 & 4127 & Economic Overfishing \\
\hline 8 & 2012 & 2106 & 3313 & 2063 & 4127 & Economic Overfishing \\
\hline 9 & 2013 & 1811 & 3313 & 2063 & 4127 & Underfishing \\
\hline 10 & 2014 & 1825 & 3313 & 2063 & 4127 & Underfishing \\
\hline 11 & 2015 & 1211 & 3313 & 2063 & 4127 & Underfishing \\
\hline \multicolumn{2}{|c|}{ Average } & 2527 & 3313 & 2063 & 4127 & Economic Overfishing \\
\hline
\end{tabular}

a Information:

Open Access: open-access condition obtained zero economic rent

Biological Overfishing: fish haul effort > MSY

Economic Overfishing: fish haul effort > MEY

Underfishing: fish haul effort $<\mathrm{MEY}$ 
Table 2. Variable cost in 2016

\begin{tabular}{|c|c|c|c|c|c|}
\hline No. & Component & Unit & Physical amount & Cost unit (IDR) & Total cost (IDR) \\
\hline 1. & Ice & Block & 100 & 10,000 & $1,000,000$ \\
\hline 2. & Fuel & Liter & 750 & 6,720 & $5,040,000$ \\
\hline 3. & Lubricant oil & Liter & 15 & 13,000 & 195,000 \\
\hline 4. & Food and cigarettes & Group (7 people) & 1 & $1,600,000$ & $1,600,000$ \\
\hline 5. & Fresh water & Water jerry can & 20 & 15,000 & 300,000 \\
\hline 6. & Forage & Set (10 kg) & 1 & 150,000 & 150,000 \\
\hline 7. & Others & - & 1 & 115,000 & 115,000 \\
\hline & & Jumlah VC & & & $8,400,000$ \\
\hline
\end{tabular}

The price assumption used in this study was the real price of $T$. albacares from 2005-2015. The real price is determined by the equation $\mathrm{P}_{\mathrm{rt}}=\left(\mathrm{P}_{\mathrm{nt}} / \mathrm{CPI}_{\mathrm{t}}\right) \times 100\left(\mathrm{P}_{\mathrm{rt}}=\right.$ real price; $\mathrm{P}_{n t}=$ nominal price; $\mathrm{CPI}_{t}=$ Consumer Price Index in the specific time $t ; \mathrm{P}_{\text {nd }}=\mathrm{CPI}$ of base year). The CPI data was obtained from the Indonesian Statistics Board to observe the real price of tuna from 2005-2015, and the average price was calculated to determine the economic index (Table 4).

\section{The optimization of tuna resource bioeconomy}

On the other side, the fishing cost will increase along with fish haul effort, creating decreasing profit $(\pi=0)$ (Table $5)$. The economic rest obtained in the tuna resource exploitation is the difference between the revenue and

Table 3. The real fish cost 2005-2015

\begin{tabular}{cccc}
\hline \hline Year & CPI & $\begin{array}{c}\text { Nominal cost } \\
\text { (IDR) }\end{array}$ & $\begin{array}{c}\text { Real cost } \\
\text { (IDR) }\end{array}$ \\
\hline 2005 & 121.56 & $8,400,000$ & $6,910,167.82$ \\
2006 & 136.67 & $8,400,000$ & $6,146,191.56$ \\
2007 & 146.04 & $8,400,000$ & $5,751,848.81$ \\
2008 & 110.75 & $8,400,000$ & $7,584,650.11$ \\
2009 & 117.73 & $8,400,000$ & $7,134,969.85$ \\
2010 & 126.54 & $8,400,000$ & $6,638,217.16$ \\
2011 & 135.37 & $8,400,000$ & $6,205,215.34$ \\
2012 & 145.45 & $8,400,000$ & $5,775,180.47$ \\
2013 & 155.57 & $8,400,000$ & $5,399,498.62$ \\
2014 & 112.52 & $8,400,000$ & $7,465,339.50$ \\
2015 & 118.67 & $8,400,000$ & $7,078,452.85$ \\
& Average value & & $6,553,612.01$ \\
& & &
\end{tabular}

the TC for capturing each condition of the resource. The highest revenue occurs in the fishing condition in the MSY point that is equal to IDR $28,789,947,370$ with the fishing cost of IDR 21,718,436,150. However, the maximum profit is at point MEY that is equal to IDR $11,167,476,240$ with the fishing cost of IDR 13,526,506,120. Figure 6 shows a comparison of the various conditions of exploitation of resources between the effort of fish haul (E), total yield (h), total revenue (TR), total cost (TC) and economic rent $(\pi)$.

The fishing effort in the MSY condition is higher than in the MEY condition (Fig. 6), indicating that in 2005-2015 the fish haul effort of actual conditions was exceeding the fish haul limitation to reach the MEY. This condition is categorized as economic overfishing.

Table 4. The calculation of real price in PPP Labuhan, East Lombok

\begin{tabular}{rrrr}
\hline \hline Year & CPI (CPI) & $\begin{array}{r}\text { Nominal price }\left(\mathbf{P}_{\mathrm{nt}}\right) \\
(\text { IDR) }\end{array}$ & $\begin{array}{r}\text { Real price }\left(\mathbf{P}_{\mathrm{rt}}\right) \\
(\text { IDR) }\end{array}$ \\
\hline 2005 & 121.56 & 40,000 & 32,906 \\
2006 & 136.67 & 40,000 & 29,268 \\
2007 & 146.04 & 40,000 & 27,390 \\
2008 & 110.75 & 40,000 & 36,117 \\
2009 & 117.73 & 40,000 & 33,976 \\
2010 & 126.54 & 40,000 & 31,611 \\
2011 & 135.37 & 40,000 & 29,549 \\
2012 & 145.45 & 40,000 & 27,501 \\
2013 & 155.57 & 40,000 & 25,712 \\
2014 & 112.52 & 40,000 & 35,549 \\
2015 & 118.67 & 40,000 & 33,707 \\
& Average value & & 31,208
\end{tabular}


Table 5. The optimization of tuna resource bioeconomy

\begin{tabular}{|c|c|c|c|c|c|}
\hline Variable & Unit & Actual condition & $\begin{array}{l}\text { Sustainable condition Bioeconom } \\
\text { (MSY) }\end{array}$ & $\begin{array}{l}\text { ny optimization } \\
\text { (MEY) }\end{array}$ & $\begin{array}{c}\text { Open Access } \\
(O A)\end{array}$ \\
\hline $\mathrm{E}$ & Trip per Unit & 2,527 & 3,313 & 2,063 & 4,127 \\
\hline $\mathrm{H}$ & $\mathrm{kg}$ & $803,182.82$ & $922,518.18$ & $791,270.90$ & $866,861.45$ \\
\hline$T R$ & IDR & $25,065,703,856$ & $28,789,947,370$ & $24,693,982,361$ & $27,053,012,230$ \\
\hline TC & IDR & $16,560,977,550$ & $21,718,436,150$ & $13,526,506,120$ & $27,053,012,230$ \\
\hline$\Pi$ & IDR & $8,504,726,310$ & $7,071,511,220$ & $11,167,476,240$ & 0 \\
\hline
\end{tabular}

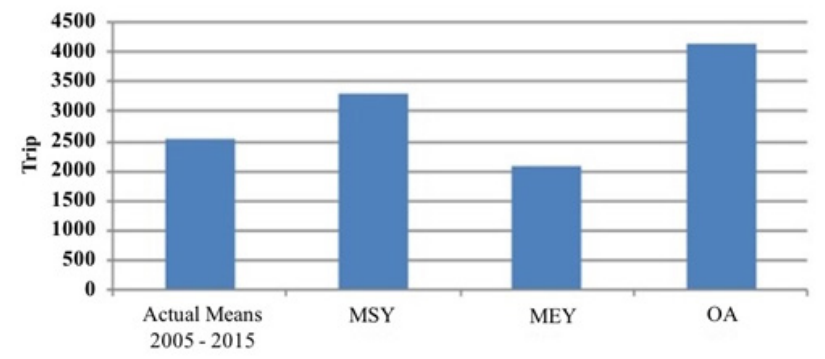

Fig 6. Comparison of the various conditions

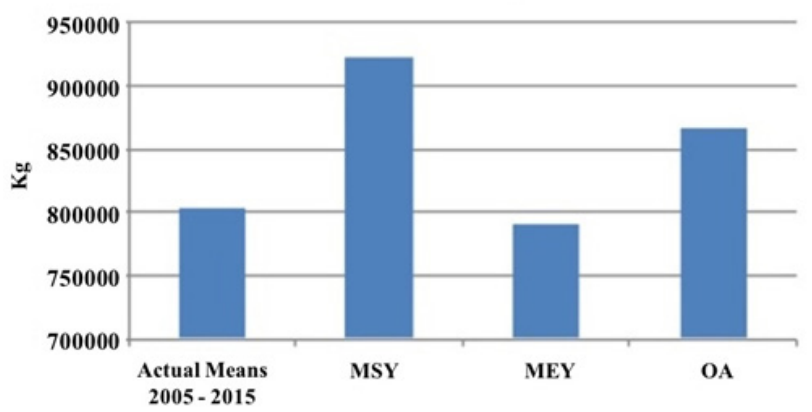

Fig 7. Comparison of fish yield in various conditions

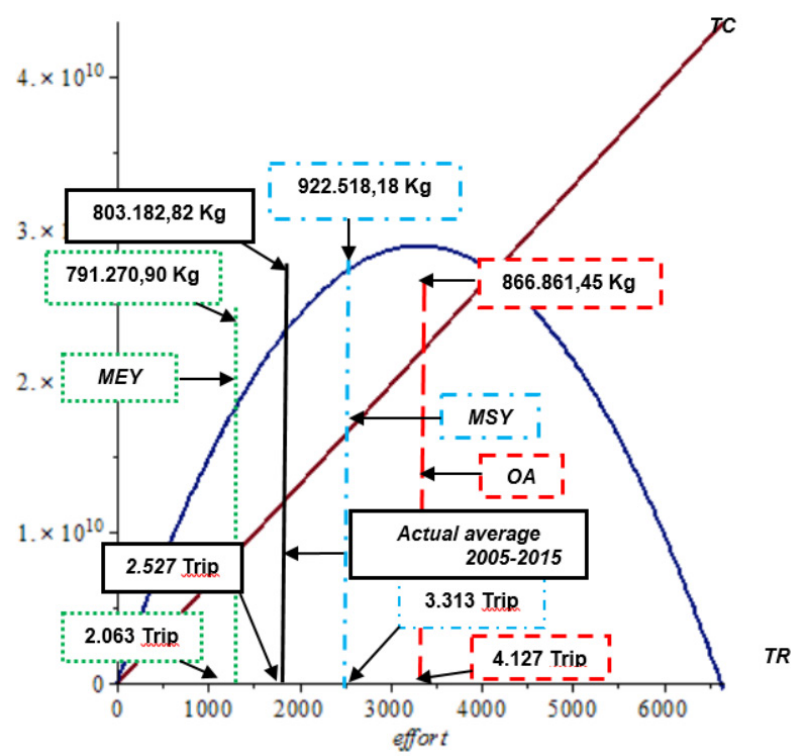

Fig 8. The quadratic relation between TR and TC in varied conditions
Figure 7 shows that fish haul in the MSY condition is higher than in the MEY condition. In the average actual condition, the fish haul yield is lower than MSY but higher than MEY. This indicates that during 2005-2015 the actual condition was exceeding the limited optimum condition. The fish yield in the open-access condition will be negative compared to the fishing effort.

For the highest field yield in the MSY condition, Effort = 3,313 per trip, $T R=$ IDR 28,789,947,370. The economic rent reached its peak in the MEY point, Effort $=2,063$ per trip, $\pi=$ IDR $11,167,476,240$. In the open-access (OA) point, it shows that $T R=T C$, therefore $\pi=0$ (Fig. 8). If the fish haul exceeds the OA point, the fishing cost will be higher than fisherman income.

\section{DISCUSSION}

The Indonesian government, as reported by Primyastanto et al. (2011), established the rule that the fish haul must not damage the sustainability of the fish resources. The $h_{m s y}$ value indicates the maximum sustainable production that is allowable to sustain the population of T. albacares without disrupting its natural balance. Regarding this result, in order to improve sustainability, fishermen are required to upgrade their fishing tools to be more environmentally friendly (Primyastanto, 2016a).

In 2006, there were open-access conditions and in 2007 the fish haul was exceeded, as indicated by the fishing trips exceeding the MSY, biologically identified as overfishing (Fig. 4). In 2006 and 2007, there were 4,352 and 3,963, respectively. However, the MSY is 3,313 trips. If the fish haul continues to perform beyond the MSY, the natural resource amount will be threatened. In 2005, 2008 and 2012, there was a decline in trips but the MEY was still exceeded $(2,063)$, a condition known as economic overfishing (Hannesson, 1988). Therefore, it required an effort to maintain the fish haul to prevent overfishing. Indonesia also established rules that limited the fish haul yield and standardized fishing tools and forbade transhipment. Starting in 2013, the fish haul activities in PPP Labuhan could be controlled; therefore, the sustainability of fish resources could still be maintained (Primyastanto, 2015). Based on the Gordon-Schaefer 
Bioeconomy Method, the effort variable and fish haul yield are dependent on cost and price. The fishing cost is based on the assumption that fishing factors are also included, so that the fishing cost is defined as variable cost (including boat fuel, fresh water, ice, forage and feed as fishing tools) per boat for one trip. This variable cost is assumed to be constant (Prakasa et al., 2014).

Price is the bioeconomically important factor since the cost variable depends on the total income of fishermen (Primyastanto, 2018a). The biological and economical aspects are surely the important issues to be studied. If the fish haul is low, the increase in effort will be followed by increased demand for fish, creating a balanced economic situation (Susanto, 2006). The effort during open-access conditions obtained zero economic rent, indicating that during the open access, fishermen gain no additional profit from their fishing effort (Atmaja and Nugroho, 2013). The higher the fishing effort, the lower the fish yield obtained by the fishermen. If this condition happens, fishermen will no longer gain profit (Primyastanto, 2016b).

The fishing effort before reaching the MSY is directly proportional to the fishing yield, total revenue and profit gained by fishermen. The higher the fishing effort, the higher the fishing yield, total revenue and profit. However, after reaching the MSY, the total fishing, total revenue and profit will decrease until it reaches the equilibrium point for open access (Anderson, 1986).

In the OA condition, there is no limitation of fishermen to haul the fish. However, economically, the OA condition will bring no profit because the income from fish haul will be divided to re-pay the cost. In addition, in the OA condition, there is plenty of fish yield that is decreasing the price (Primyastanto, 2017a). To gain more profit, the fishermen will likely increase effort to haul more fish, even to optimum fish yield and beyond. This leads to natural resource disruption because the natural availability of the fish is disrupted by overfishing and non-eco-friendly fishing tools (Bengen, 2001).

The optimum level of maintaining $T$. albacares fish haul is maintaining the MEY instead of MSY. Determining the profit requires not only paying attention to income but also to cost, and the difference between the two is the profit for fishermen. The highest fish haul is on the MSY point, but the cost of MSY is higher than MSE. Therefore, the economic rent is on the MEY point (Fauzi, 2006).

In the actual conditions of 2005-2015, the tuna fishing effort was categorized below sustainable production. Although based on calculations, the actual condition was lower than the MSY condition, and there was a probability that biological and economical overfishing occurred in certain years (Gordon, 1954) because of over-exploitation during 2006-2007 (Table 1). If the OA and overfishing continues, certainly it will damage the sustainability and disrupt the natural condition (population) of $T$. albacares. Therefore, the government is required to make rules related to limiting fish haul, sorting the sea areas that fishermen are allowed to fish and maintaining the fish yield. Moreover, it requires a brief rule about the fishing tools that are allowed and forbidden in fish haul, which is related to the tool's environmentally-friendly qualities (Primyastanto, 2017b).

In conclusion, $T$. albacares has promising potential as a fish resource and is mainly collected by relatively environmentally-friendly equipment. In 2006 and 2007, open-access and biological overfishing occurred, respectively. In 2005 and 2008-2012, economic overfishing occurred. The maximum operation in PPP Labuhan occurred in the MEY condition, with fish yield reaching $791,270.90 \mathrm{~kg} /$ year, for 2,063 fish haul trips, which is yielding the economic rent for IDR 11,167,476,240.

The government needs to establish a clear rule of limitation to standardize the fish haul or trip to maintain natural sustainability. This is expected to make the economic rent as optimal and efficient as possible. Further study using the Gordon-Schaefer Model approach is needed to statistically study the fish haul and other fish commodities. The biological condition of Indonesian seas, especially the most promising areas as fish producers, need to be studied to maintain the natural condition and limit the natural disruption. It is highly recommended to use environmentally-friendly fishing tools, required to know the information about utilization and managing the maritime potential. The knowledge will increase the awareness to take a part in maintaining the natural sustainability of the sea commodities as a consumer.

\section{ACKNOWLEDGMENTS}

We thank the Directorate General of Higher Education, Ministry of Education and Culture. Based on Official Decree No:167/SP2H/LT/DRPM/2019 and Agreement Letter No: 332.16/UN10.C10/PN/2019. We also thank the State Civil Apparatus in PPP Labuhan East Lombok and all related parties.

\section{ODRŽIVA OPERATIVNA ANALIZA S BIOEKON- OMSKIM PRISTUPOM UZGOJA INDONEZIJSKOG Thunnus albacares}

\section{SAŽETAK}

Cilj ove studije bio je opisati karakteristike i uvjete uzgoja Thunnus albacares u području Pelabuhan Perikanan Pantai (PPP, obalno-lučkom području) Labuhan Lomboka u Istočnom Lomboku. Podaci su prikupljeni jednostavnim slučajnim uzorkom s 30 ribarskih brodova pomoću upitnika. Primarni podaci prikupljeni su razgovorom s ispitanicima i terenskim promatranjem, dok su sekundarni podaci prikupljeni iz evidencije PPP-a u Labuhan Lomboku, BPS i DKP, Istočnog Lomboka. Rezultati su pokazali da Istočni Lombok ima veliki potencijal za uzgoj T. albacares, kao i za ekološki uzgoj ribe; to prakticiraju lokalni ribari koji obično 
koriste tradicionalne čamce veličine 4-7 BT u kompletu $\mathrm{s}$ ribolovnim alatom, uključujući ručne štapove. Prema biološkom aspektu 2006. godine bio je otvoren pristup ulovu T. albaceros, nakon čega je uslijedio biološki prelov 2007. godine i gospodarski prelov 2005., 2008., 2009., 2010. i 2011. godine. Maksimalni održivi prinos (MSY) dosegao je 922.518,18 kg godišnje (s razinom MSY-a 3.313 godišnje). Optimizacija resursa T. albaceros dosegla je vrhunac maksimalnog ekonomskog prinosa (MEY) procijenjenog na 24.693.982.361 IDR, uz 2.063 godišnja ribolovna izlazaka, što čini 791.270,90 kg tune godišnje.

Ključne riječi: maksimalni održivi prinos, najveći ekonomski prinos, resurs tune, ekonomski prelov, biološki prelov

\section{REFERENCES}

Anderson, L. G. (1986): The Economic of Fisheries Management. USA, The John Hopkins University.

Atmaja, S. B., Nugroho, D. (2013): Optimisasi Hasil Tangkapan Perikanan Pukat Cincin di Perairan Laut Jawa dan Sekitarnya [Caches optimization of trawling fishing in the Java Sea and surrounding waters]. Jurnal Litbang Perikanan Indonesia, 19, 2, 1-9. (in Indonesian).

Bengen, D. G. (2001): Ekosistem dan Sumberdaya Alam Pesisir dan Laut [Ecosystems and Natural Resources of Coastal and Marine]. Bogor (INA), Pusat Kajian Sumberdaya Pesisir dan Lautan, Institut Pertanian Bogor (in Indonesian).

Dahuri, R. (2008): Restrukturisasi Manajemen Perikanan Tuna [Management Restructuring of Tuna Fisheries]. Jakarta (INA), Samudera Komunikasi Utama (In Indonesian).

Fauzi, A. (2006): Ekonomi Sumberdaya Alam dan Lingkungan [Economics of Natural Resource and Environment]. Jakarta (INA), Gramedia Pustaka Utama.

Fauzi, A. (2010): Ekonomi Perikanan [Economic of Fisheries]. Jakarta (INA), Gramedia Pustaka Utama.

Fishbase. (2016): The distribution of Thunnus albacares. [cited 2016 April 2]. Available from https://www. fishbase.in/search.php.

Gordon, H. S. (1954): The Economic Theory of a common property resource the fishery. Journal of Political Economy, 62, 1-8.

Habibi, A., Ariyogagautama, D., Sugiyanta. (2011): Perikanan Tuna-panduan penangkapan dan penanganan [Fisheries of Tuna - Guide of Capturing and Handling]. WWF, Indonesia (in Indonesian).

Hannesson, R. (1988): Economics of Fisheries. Jakarta (INA), University of Indonesia (UI-Press).

Hasan, M. I. (2002): Pokok-Pokok Materi Metodologi Penelitian \& Aplikasinya [Highlights of Material of the Research Methodology \& its Application]. Jakarta (INA), Ghalia Indonesia (in Indonesian).

Ministry of Marine Affairs and Fisheries. (2014): Provinsi Nusa Tenggara Barat [Province of West Nusa Tenggara]. [cited 2015 January 15]. Available from http://dislutkan. ntbprov.go.id/content/pelabuhan-perikanan-labuhanLombok. (in Indonesian).

Pradana, W. T. (2015): Analisis bioekonomi sumberdaya Ikan tuna (Thunus sp) Di perairan kabupaten Pacitan Jawa Timur [Bioeconomic analysis of tuna fish resources (Thunus $s p$ ) in the waters of Pacitan district], East Java. Malang (INA): Brawijaya University, Malang (in Indonesian).

Prakasa, G., Boesono, H., Ayunita, D. N. N. D. (2014): Analisis Bioekonomi Perikanan untuk Cumi-Cumi (Loligo sp) yang Tertangkap dengan Cantrang di TPI Tanjungsari Kabupaten Rembang [Analysis of Fisheries Bioeconomic for Squid (Loligo $s p$ ) Caught with Cantrang at TPI Tanjungsari, Rembang Regency]. Journal of Fisheries Resources Utilization Management and Technology, 3, 2, 19-28 (in Indonesian).

Primyastanto, M. (2015): Economic Analysis of Pandega Fishermen Household at Madura Strait to Keep Food Security. International Journal of Oceans and Oceanography, 9, 2, 97-104.

Primyastanto, M. (2016a): Effect the usage of axle and second ship helper on fish capture of purse seine fishermen in Banyuwangi District, Indonesia. Asian Journal of Microbiology, Biotechnology \& Environmental Sciences, 18, 2, 297-303.

Primyastanto, M. (2016b): Feasibility study of fish capture with payang tool before using electronic Onjhem Fads in madura strait indonesia. International Journal of Business and Economics Research, 14, 9, 6615-6628.

Primyastanto, M. (2017a): The Cobb-Douglass Production Function Model on Trawling Fishermen in Probolinggo, East Java. International Journal of Economic Research, 14, 10, 1-7.

Primyastanto, M. (2017b): Ilmu Kelautan dan Perikanan (Kebijakan Pembangunan dan Pengelolaan Sumberdaya Perikanan dan Kelautan) [Development and Management Policy of Fisheries and Marine Rosources]. Jakarta (INA), Intrans Publishing (in Indonesia).

Primyastanto, M. (2018a): Household economic models of gill net fishermen at madura strait. In: IOP Publishing IOP Conf. Series: Earth and Environmental Science. 137, 012103.

Primyastanto, M. (2018b): Ekonomi Produksi Perikanan dan Kelautan Modern, Teori dan Aplikasinya [The economics of Modern Fisheries and Marine Production: Theory and Its Applications]. Malang (INA), UB Press (in Indonesia).

Primyastanto, M., Sahri, M., Fitri, L. (2011): Pendekatan Bio-Ekonomi pada Pengelolaan Sumberdaya Ikan Berkelanjutan [Bio-Economic Approach on the Sustainable Management of Fish Resources]. Malang (INA), PPS UB (in Indonesian).

Saanin, H. (1984): Taksonomi dan Kunci Identifikasi Ikan [Taxonomy and Identification Key of Fish]. Bandung (INA), PD Grafika Unit II (in Indonesian). 
Schaefer, M. B. (1954): Some Aspects of the Dynamics of Populations Important to the Management of Commercial Marine Fisheries. Inter-American Tropical Tuna Commission Bulletin, 1, 2, 23-56.

Sobari, M., Daniah, P., Widiarso, D. I. (2004): Analisis Maximum Sustainable Yield dan Maximum Economic Yield Menggunakan Bio-Ekonomik Model Statis Gordon Schaefer dari Penangkapan Spiny Lobster di Wonogiri [Analysis of "Maximum Sustainable Yield" and "Maximum Economics Yield" Use Bio-economics Static Models of Gordon-Schaeffer from Spiny Lobsters Capture on Wonogiri]. Bogor: Bogor Agricultural University (in Indonesian).

Sudirman, H., Mallawa, A. (2004): Teknik Penangkapan Ikan [Fishing Methods]. Jakarta (INA), Rineka Cipta (in Indonesia).
Sumandhiharga, O. K. (2009): Ikan tuna [Tuna Fish]. Jakarta (INA), Research Center of Oceanography - LIPI (in Indonesian).

Supadiningsih, C. N., Rosana, N. (2004): Penentuan Fishing Ground Tuna dan Cakalang dengan Teknologi Penginderaan Jauh (Pertemuan Ilmiah Tahunan I) [Determination of Tuna and Skipjack Fishing Ground with Remote Sensing Technology (Annual Scientific Meeting 1)]. Surabaya (INA), Sepuluh Nopember Institute of Technology (in Indonesian).

Susanto. (2006): Kajian Bioekonomi Sumberdaya Kepiting Rajungan (Portunus pelagicus L) di Perairan Kabupaten Maros, Sulawesi Selatan [Bioeconomic study of Rajungan crab (Portunus pelagicus L) resources in Maros Regency, South Sulawesi]. Jurnal Agrisistem, 2, 1-5 (in Indonesian). 